\title{
Teaching Teachers about Astronomy
}

\author{
Coggin Heeringa \\ Crossroads at Big Creek
}

\begin{abstract}
Crossroads at Big Creek, in collaboration with the Door Peninsula Astronomical Society, is dedicated to educational outreach in astronomy. We have had our best results by providing teacher education in the form of continuing education classes and workshops.
\end{abstract}

\section{Background}

Crossroads at Big Creek, Inc. in Sturgeon Bay, Wisconsin is a learning preserve dedicated to life-long learning in science, history and the environment. The preserve includes an Astronomy Campus which includes the Leif Everson Observatory \& StarGarden (owned by the School District of Sturgeon Bay) and the Ray and Ruthie Stonecipher Astronomy Center which houses an inflatable planetarium.

For more than a dozen year, in collaboration with the Door Peninsula Astronomical Society, Crossroads offered classes and events designed to introduce the public to astronomy and to interest young people in the STEM disciplines.

Through the years, Astronomy Days, night sky viewing, lectures, and youth programs were offered with limited participation. Those who did attend were predominantly families in which the parents had prior interest in astronomy. In short, we were "preaching to the choir."

Unlike Baby Boomers, parents of today did not grow up during the Space Race. They did not cheer for Alan Shepard, pray for John Glenn, or thrill to the moon landings. They probably did not dream of growing up to be astronauts. To them, the term "rocket science" became a metaphor for something beyond comprehension. In short, as a group, they simply were not interested in space-related topics and consequently, did not bring their children to astronomy outreach activities.

Clearly, if our outreach efforts were to reach children, we would have to work through the elementary schools. But most teachers were in the same generation as the parents of their students and in too many [though, thankfully, not all] cases, were attracted to elementary education because science and math requirements were minimal.

Students become excited about topics presented by passionate teachers. If we could increase the content knowledge and enthusiasm for astronomy in elementary school teachers, we believed that they would inspire their students. Better than we could. After all, teachers really are the best teachers.

This project was underwritten with a grant from the Wisconsin Space Grant Consortium. 


\section{Methods}

The idea for reaching teachers occurred during a focus group trying to promote sustainability at Crossroads. A retired teacher made the offhand remark, "Teachers have to have continuing education, but the cost of graduate level courses is so excessive, they'll sign up for any flying circus if they can get a credit cheaply."

This was it! We could be the flying circus. If we would offer a generous scholarship stipend, teachers would sign up for a class in astronomy. Crossroads already had a working relationship with the University of Wisconsin-Green Bay Education Outreach program to offer graduate level methods classes and they approved the course "Teaching Astronomy in the Elementary School" and with the success of that added a second course, "Interactive Astronomy in the Elementary School." A generous scholarship stipend (funded through WSGC) made these classes almost irresistible to teachers, many of whom had little or no prior interest in space education.

The plan worked. In fact, participating teachers went back to their schools and incorporated activities into their classes. Seeing their excitement, teachers who did not need credits asked if we could offer workshops as well.

Using funds from WSGC, we began offering workshops on astronomical topics: "The Real Stars of Harry Potter"; "Comets"; "Green Lasers and Lasagna"; Night Sky Constellations". We offered a free dinner, teaching materials and a stipend, and invited the teachers to bring their children and spouses along. The "bring the children" was included so teachers would not have to pay a babysitter, but it turned out to be the best part of the program. Teachers could observe how excited the children got while doing the activities.

Watching teachers leading children through hands-on activities spawned yet another idea. Teachers are great teachers. Why not hold our workshops immediately prior to outreach activities? Workshop participants could receive a small stipend for attending the training or a larger stipend if, after learning the activities, they would stay and become presenters at our outreach events.

\section{Conclusions and Future Plans}

The best evaluation of our programs is the increase in astronomy-based school field trips to Crossroads and the increase prior knowledge the children have when they visit our planetarium. We can immediately recognize the student of teachers who have participated in our programs. We also have tripled our participation at outreach events. Apparently, teachers who will be presenting activities encourage their students to attend the events.

We will be offering a teacher workshop on exo-planets October 1 prior to our Family Astronomy Day and also offering a one graduate hour class "Teaching Astronomy in the Elementary School" through UW-Green Bay October 7, 8, and 15. 2011. 